\title{
POLONISATION AND ALL THAT, OR RELIGIOUS IDENTITY AND CULTURAL CHANGE IN RUTHENIA: THE UNION OF LUBLIN AND THE MYTHS OF «POLONISATION»
}

\begin{abstract}
Полонізація і таке інше, або релігійна ідентичність і культурні зміни в Україні-Русі: Люблінська унія та «полонізаційні» міти.

Запропоновано перегляд застарілої тези в історіографії про те, що кардинальним наслідком Люблінської унії Речі Посполитої 1569 р., через яку українські землі Великого князівства Литовського стали складовою частиною Королівства Польського, була примусова полонізація православного населення. На заміну цій спрощеній схемі напрацьована автором модель бере за основу асиміляційну формулу, згідно з якою саме релігійні конверсії другої половини XVI ст., що призвели до переходу ряду представників православної шляхти спочатку до протестантських конфесій, а згодом у католицизм, стали першим кроком до втрати ними самоідентифікації з культурним простором України-Русі.

Ключові слова: історіографія, Люблінська унія 1569 р., Брестська церковна унія 1596 р., полонізація, релігійні конверсії, самоідентифікація.
\end{abstract}

The incorporation of three Ukrainian palatinates to the Polish Crown under the Union of Lublin led to cultural change in those territories. Many a historian would pause before venturing beyond this bald statement. Principal exceptions are $19^{\text {th }}$ century populist historians and scholars seemingly unafraid of sounding partisan. By name or by extension, the concept of «polonisation» mostly obtains at this level of historical debates.

Mykhailo Hrushevsky is a prominent representative of the cohort of historians for whom the onset of «polonisation» coincided or markedly intensified with the conclusion of the real union of two nations in 1569 . He viewed the «polonisation» and «latinisation» of the newly incorporated territories as such «that flowed logically from the very foundations of the Polish regime» [1]. This suggests that a deliberate imposition of Polish customs took place in the Lithuanian and Ruthenian contexts: «As a result of close association with Poland, political structure, social relations, culture, and private life were all subjected [my emphasis] to profound polonization from the mid-sixteenth to the mid-seventeenth centuries» [2]. The main problem with this thesis is the contradiction inherent,

() Л. В. Шаріпова, 2016 
on the one hand, in Hrushevsky's successful demonstration that «polonisation» was in fact a long-term phenomenon that reached back with its roots to the $14^{\text {th }}$ and $15^{\text {th }}$ centuries, and, on the other hand, in his effort to represent it as a process sponsored by the Polish state from around the mid-1560s, which appears less persuasive [3]. Other significant aspects of Hrushevsky's view of «polonisation» include its allegedly passive acceptance by the Ruthenian noble elite, offset by the active and effective resistance of the popular element: burghers and even peasants. Furthermore, true to the populist paradigm, those Ukrainian nobles who escaped «polonisation» were described as poorer and less educated than their Polish and «polonised» neighbours. Consequently they had little choice but to keep «closer to the popular masses ... not voluntarily but by force of circumstance» [4]. Hrushevsky emphasised the deleterious effect of the CounterReformation on the preservation of Ruthenian identity, but denied any lasting significance to the spread of Evangelical belief. His summary assessment of the impact of the Union of Lublin on Ukrainian cultural life was negative.

Attractive in its simplicity, this model has been frequently deployed by the historiographic traditions that tend to view Ruthenian Orthodox culture as an object of external influence. The irony is that these traditions are often situated at the opposite ends of the axiological spectrum. Let us consider a few examples. An article by Lucjen Lewitter published soon after WWII offers a splendid vision of Poland's civilising mission in the eastern kresy:

By the middle of the $17^{\text {th }}$ century Roman Catholicism was established as the religion of the vast majority of the White Russian and the Ukrainian nobility. This was not brought about by Jesuit intrigue or coercion on the part of the state, but by the indisputable superiority of Polish over Ruthenian culture and by its indispensability to the szlachta of those regions as one of the attributes to the Republic's governing class, whether on the Vistula or on the Dnieper, where now to be civilised was to be polonised [5]. Orest Subtelny's magisterial Ukraine: a history, first published in 1988, presents an almost identical picture:

The attractive Polish model of privileged nobleman exerted a powerful assimilatory influence on the Ukrainian nobility. And the obvious superiority of its culture intensified the appeal of all things Polish. The Jesuits, sure of their victory over Protestantism, now focused their attention on the «schismatics», as they called the Orthodox. Soon after 1569, they moved into Ukraine [...]. For status conscious Ukrainian noblemen ... their association with a religion and culture that was considered to be inferior was extremely galling. As a result, they abandoned the faith of their forefathers in droves and embraced Catholicism along with the Polish language and culture [6]. 
With regard to the language, two things have to be borne in mind. First, by the $16^{\text {th }}$ century Polish was widely used throughout the Grand Duchy, so, being effectively bilingual, Ukrainian nobles did not really have to learn a new language after 1569. Second, the Union of Lublin recognised Chancery Ruthenian as the language of administration in the three newly incorporated palatinates. It remained the official language of the Grand Duchy of Lithuania until 1696, although Polish and Latin became established there as well [7]. This means not so much that the attitude of the Commonwealth was particularly «enlightened», but only that «polonisation» was not part of a state-sponsored programme. Piotr Skarga's insistence on the inferiority of Church Slavonic represented an attack on the sacral language of Slavia Orthodoxa and can hardly be regarded as an argument in favour of Polish language and culture.

Paul Robert Magocsi's A history of Ukraine, first published in 1996, displays a somewhat more nuanced, but nonetheless broadly similar vision of the inferiority- and envy-induced secession of the Ukrainian nobility:

Given this atmosphere, it is not surprising that the Lithuanian and Orthodox Rus' nobility in the east were attracted as by a magnet to sixteenth-century western-oriented Polish culture. Many of them aped Polish customs, adopted the Polish language, and, in the case of the Rus' converted to Roman Catholicism, the official state religion [my emphasis]. As for that portion of the Rus' nobility (whether in Lithuania or in Ukraine) who remained Orthodox, Polish political identity became an important element in their outlook. It is precisely from this segment of the Ukrainian nobility that the concept gente Ruthenus, natione Polonus ... developed. In this regard, it is interesting to note that in 1569 ... it was the Rus' magnates and gentry who for the most part wanted the remaining Ukrainian lands in Lithuania ... to become ... an integral part of Poland [8].

It is indeed an axiom that the Union of Lublin had broad support from Lithuanian and Ruthenian nobility, who were desirous of securing for themselves the privileges enjoyed by their Polish counterparts. But the evidence that this desire was dictated by the sense of cultural inferiority, rather than political opportunism, is scant. On the contrary, in the course of the debates that preceded the Union, a group of proud Volhynian gentry declared themselves to be «respectable people equal in faith and honor to ... [Poles] in every way» [9]. Another telling sign of self-confidence is the fact that on becoming part of the Commonwealth, the Ruthenian nobility eschewed the Polish institution of heraldic families or armorial clans (ródy herbowni) and continued to use the traditional system of individual family crests. At the turn of the $17^{\text {th }}$ and $18^{\text {th }}$ centuries Ruthenian and Lithuanian family crests still constituted nearly a half of noble heraldic devices used in the Polish-Lithuanian Commonwealth [10]. 
At their heart early modern identities across Europe were defined by the dual principle of regionalism and cultural commonality based on religion [11]. After 1569 the three Ruthenian palatinates were also characterised by specific legal and administrative practices that obtained there. I would argue that the more inclusive aspects of identity such as being part of the privileged noble nation of the Commonwealth, living under one monarch, or subscribing to the myth of common Sarmatian origin were significant, yet peripheral. Therefore they were unlikely to present a challenge to the core values of regionalism and religion.

In an article intended for the popular audience published in 1994, Natalia Yakovenko draws a link between 1569 and the «de-nationalisation of local [Ruthenian] aristocratic leadership, which undermined the unity of national elite whose task ought to have been the expression and fulfillment of the political aspirations of the Ukrainian people. The Union [of Lublin] was followed with the blind, ruinous offensive of the Catholic Church supported by the state» [12]. She goes on, however, to dispense with some other long-standing historiographic myths, such as the speedy substitution of Ukrainian landlords with Polish ones in the newly incorporated regions, or immediate changes in the political and cultural world-view of their population at large [13]. Unlike Hrushevsky, Yakovenko's summary assessment of the effects of the Union, particularly in the sphere of political culture, is positive. She points out the Ukrainian szlachta's emerging sense of civic duty, development of local self-government, and the impact of the territorial administrations on state policy. But she does not consider these changes to be part of the process of «polonisation» [14].

As the historical accounts cited above demonstrate, following in the footsteps of the "father of Ukrainian historiography», $20^{\text {th }}$-century historians of Ukraine have largely disregarded the role of Protestantism in effecting a cultural transformation in Ruthenia. They have also tended to collapse the events of the century that followed 1569 into a seemingly uniform, indistinguishable whole. While it is hard to deny that the process of «polonisation» of the Ukrainian elite was well under way by the 1650 s, extending it backward by nearly a hundred years until it reaches a convenient starting point that marks the incorporation of the Ukrainian lands to the Polish Crown, is problematic. To begin with, it is not a foregone conclusion that political developments, however momentous, are capable of engendering cultural change across the board. Unlike acts of political union (or political disintegration), which take place on a given date and lead to more or less instant redrawing of borders, cultural change is a long-term cumulative process that involves a gradual transformation of identity and occurs when people's core beliefs are challenged.

As the starting point of my discussion of the course of «polonisation» of Ukraine I would like to apply Frank Sysyn's elegant formula: 
In the seventeenth century numerous Ruthenian nobles ... went through the process of assimilation in stages ... they first became members of the Polish political nation; then they adopted the language, culture and life style of the Polish nobility; later, they converted to Catholicism or Protestantism; finally they lost all feelings of separateness from the nobles of the Polish territories [15].

Below I would like to focus on the religious side of that process.

My thesis is two-fold. First, the widely accepted chronology that explicitly links the onset of «polonisation» with the conclusion of the Union of Lublin, calls for revision. «Polonisation» as a cultural phenomenon should be backdated to the late medieval period. This would help to remove the anachronistic equation between a forced imposition of Polish customs upon the Ruthenian populace and a natural trend that occurred more or less by osmosis. Here we should take heed of Yakovenko's warning to resist the impulse whereby «everything non-Ukrainian found in the [Ukrainian] 'national' space becomes associated with an aggressor set to conquer 'our' land, overcome 'our' faith, 'our' people, etc.» [16]. The beginning of «polonisation» as a cultural process driven by external agents needs to be placed at the turn of the $16^{\text {th }}$ and $17^{\text {th }}$ centuries. What we end up with, then, are two overlapping cultural trends in place of one.

My second substantive point is that the period in Ukraine's religious history from the time of the arrival of Protestantism in the middle of the $16^{\text {th }}$ century to the late 1590s marked an important watershed between the two "polonisations». A strong link has been traditionally drawn between «polonisation» and «catholicisation» in the historiography. But that no connection seems to have been established between cultural change and the Evangelical movement in the Ruthenian lands, is a weakness. A whole chunk of dense and involved history is missing in this model. What remains seems to be based on little more than popular equation between being «Polish» and being «Catholic», characteristic of the bitter divisions of the second half of the $17^{\text {th }}$ century. Following the partitions of Poland, it was effectively redeployed by $19^{\text {th }}$-century historians and became a projection of imperial expansions in the same territory. As such this equation has little in common with the much more confessionally mixed $16^{\text {th }}$ century.

Generally speaking, the spread of Protestant ideas and practices in the Ruthenian lands of Poland-Lithuania is an undeservedly ignored subject. Historians with their minds fixed on Catholic ascendancy after the Church Union of Brest, often downplay the significance of Evangelical trends or dismiss them as irrelevant [17]. A close analysis of the religious situation in Poland and Lithuania in the five median decades of the $16^{\text {th }}$ century, however, reveals a much 
more varied picture. Lutheranism and Anabaptism arrived in Poland in the $1520 \mathrm{~s}$ and $-30 \mathrm{~s}$, and the 1540s witnessed the appearance of Calvinism. By the early 1560 s the Reformed faith all but conquered Lithuania, including representatives of the leading Ruthenian clans: the Chodkiewiczes, the Puzynas, the Sapiehas, the Wiśniowieckis, and the Wolowiczes, to name but a few [18]. The same decade marked the arrival and rapid success of Antitrinitarianism. The 1573 Warsaw Confederation enshrined the principle of religious toleration in the Commonwealth's constitution. It became a veritable safe haven for a variety of Evangelical movements, allowing them to thrive on a scale unprecedented almost anywhere else in Europe. Magnates, such as the eminent patron of Orthodox religion and culture Prince Constantine Ostrozskii (1526-1608) showed an interest in Evangelical teaching and extended their patronage to Protestant scholars. Aided by the growing number of inter-confessional marriages, this created an atmosphere of «confessional openness», in Yakovenko's words [19]. Characteristic of the turn-of-the-century Commonwealth, it was replaced with much more stringent criteria of religious conformity a hundred years later, but this represents a whole different story.

In the realm of religious publications, in addition to multiple earlier translations of the New Testament, the complete Calvinist Bible in Polish sponsored by Nikolaj Radziwiłł «the Black» was printed in Brest in 1563. The increasing availability of Protestant biblical translations into the universally accessible Polish language already caused some anxiety among the Orthodox. But the appearance of the Protestant Bible and printed catechisms in Ruthenian was an unambiguous sign of Evangelical proselytising aimed specifically at Orthodox audiences. In 1562 the Calvinist pastor Szymon Budny published a Ruthenian catechism in Nieśwież. He intended it for the use of «the simple folk of Ruthenia and for small Ruthenian Christian children» (dlia prostogo naroda russkogo i dlia khristianskikh detok russkikh) [20]. This was part of a bigger picture: as observed by Maria Crăciun, attempts at the dissemination of Protestant translations of Scripture and other works in Romanian printed in Germany among the Orthodox population of Moldavia in 1562-1563, was an indication of the European Evangelical Reformers' «interest in fostering the Reformation in Orthodox settings» [21].

In George Williams's estimation, by the 1570 s nearly 400 Protestant congregations, mostly Antitrinitarian, existed in Ruthenia alone [22]. In 1588-1591, there were only 28 Catholic senators against 42 seats held in the upper chamber of the national Diet by Protestants and Orthodox [23]. A probably much inflated statistic used by Skarga reveals that in the Navahrudak region of Lithuania, only sixteen out of about 600 Orthodox noble families had managed to resist Evangelical proselytising [24]. Even if the venerable Jesuit overstated his case, 
and the numbers do not, strictly speaking, apply to the Ukrainian lands, the question of the appeal of Protestantism to different strata of Ruthenian nobility is a real one. Not least because under the terms of the Warsaw Confederation, a lord who converted to another religion had the right to demand that the population living on his estates followed suit [25]. Contrasted with the set ways and frequently low level of education displayed by Orthodox clergy, Protestant fervency of belief and intellectual appeal exerted a powerful attraction upon many Orthodox nobles. The new religion also held the promise of relieving them from the episcopal power and promoting noble leadership in church affairs. It is important to bear in mind that noble conversions to Protestantism were voluntary, induced neither by pressure from the state, nor, it seems, by particular considerations of prestige [26]. With their freedom constitutionally guaranteed, they were part of the on-going phenomenon of cultural change.

Protestant examples offered different, but no less attractive opportunities to the Ruthenian burgesses, who, compared to the nobility, were not as well protected from religious discrimination in an urban setting. Both endogenous and exogenous factors were at play here, but claims in the historiography that in the atmosphere of the Commonwealths' religious pluralism a church in which the laity insisted on choosing their priests and studying scripture, controlling the printing presses and scrutinising the conduct of bishops, was unaffected by Protestantism, do not ring true. By the time when the six-year period of intense Orthodox synodal activity was launched in 1590, «protestantising» burgers were joined in their struggle against the episcopate by a segment of Orthodox nobility. The laity also garnered support from the Eastern patriarchs. These divines were motivated both by legitimate pastoral concerns and by the desire to maintain their traditional influence in the Orthodox lands of Poland-Lithuania. In Ambroise Jobert's words, they viewed the region as an important theatre of a «triangular [confessional] struggle» between the Orthodox Church, Protestantism and Rome [27]. Yet again the laity's choices were dictated by developmental struggles within the Orthodox Church itself and thus voluntary.

The significance of Evangelical conversions and lay movements inspired by Protestant examples should be considered on several levels. To begin with, they provoked a strong reaction on the part of the Orthodox episcopate, who sought to oppose «protestantising» trends by strengthening church hierarchy and denying the laity any real say in ecclesiastical affairs. In his book on the genesis of the Union of Brest Borys Gudziak has amply demonstrated to what extent the fear of Protestantism drove Orthodox bishops toward a rapprochement with Rome [28]. Bearing in mind the Ruthenian episcopate's legally enshrined aristocratic status, the religious conflict between the bishops and the laity also had distinct social undertones. 
Secondly, early successes of Protestantism undermined the sacrosanct status of the traditional faith as a core element of Ruthenian identity. Similar to their counterparts in Central Europe, some Ruthenian converts kept moving from one Protestant confession to another, often increasingly radical in nature [29]. For some, who, like the future Metropolitan Ipatii Potsii, returned to the Orthodox fold after a period of infatuation with Calvinism, subsequent conversion to Catholicism could have been made easier. Those nobles for whom the pull of Evangelical doctrines had been insufficiently strong, could still be dismayed by the discovery that after 1596 they belonged to a church that in effect had no legal standing with the state. Overt appeals to prestige and social advancement would have sounded ambiguous to the proud nobility of the Kyïvan and Volhynian Palatinates at the time of their incorporation to the Crown. But belonging to a confession that not only had been made to look uncouth, but was also illegal, devoid of proper hierarchy, and could not handle property, was another matter. Later on considerations of prestige motivated status-conscious laity and clerics to convert from Greek to Roman Catholicism.

The combination of a loss of claim to exclusive loyalty on the part of the Orthodox Church following the Evangelical conversions of the 1560s and -70s, its lack of legality since 1596, and the attendant anxiety about status on the part of Ruthenian nobility, upset old religious certainties. From the turn of the century, «polonisation» ceased to be a natural phenomenon and became a process sponsored by the crown and supported by the increasingly vocal and dominant Catholic segment of the Commonwealth's social elite. In the $17^{\text {th }}$ century Orthodox nobles faced a difficult choice between tradition and prestige, freedom and power, honour and status. While some Ruthenians managed to resist external pressure, to others, whose core identity had already been compromised in the confessionally permissive earlier period, ultimate cultural change may have been a natural course.

To sum up, I propose to rearrange the components of Sysyn's «assimilation formula» cited earlier as follows. Religious conversions of the $16^{\text {th }}$ century: Protestant and later Catholic, heralded the alienation of part of the Ruthenian elite from traditional culture. It intensified after the Orthodox Church lost its legal status after the Union of Brest. Eventually this led to their self-identification with other nobles from the Polish territories, an overwhelming majority of whom were now Catholic. The political Union of Lublin could only have had a symbolic role to play in that process. 


\section{References}

1. Hrushevskyi, M. (2012). Istoriia Ukrainy-Rusy [History of Ukrainy-Rus]. Vol. 6. Zhytie ekonomichne, kulturne, natsionalne 14-17 vikiv [Economic, cultural, and national life in the 14-17th centuries (p. 206). Alberta, Toronto. [In Ukrainian].

2. Hrushevskyi, M. (2012). Istoriia Ukrainy-Rusy [History of Ukrainy-Rus]. Vol. 6. Zhytie ekonomichne, kulturne, natsionalne 14-17 vikiv [Economic, cultural, and national life in the 14-17th centuries (p. 219). Alberta, Toronto. [In Ukrainian].

3. On the adoption of Polish administrative, legal and social models in the Grand Duchy of Lithuania since 1386, see Sysyn, F. E. (1982). Regionalism and political thought in seventeenth-century Ukraine: the nobility's grievances at the diet of 1641 . In Harvard Ukrainian Studies, 6, 2, p. 169. [In English].

4. Hrushevskyi, M. (2012). Istoriia Ukrainy-Rusy [History of Ukrainy-Rus]. Vol. 6. Zhytie ekonomichne, kulturne, natsionalne 14-17 vikiv [Economic, cultural, and national life in the 14-17th centuries (p. 190). Alberta, Toronto. [In Ukrainian].

5. Lewitter, L. R. (1948). Poland, the Ukraine and Russia. In The Slavonic (and East European) Review, 27, p. 169. [In English].

6. Subtelny, O. (2005). Ukraine: a history (4th ed., pp. 94-95). Toronto. [In English].

7. Sysyn, F. E. (1985). Between Poland and the Ukraine. The dilemma of Adam Kysil, 1600-1653 (pp. 19, 21). Cambridge, MA. [In English].

8. Magocsi, P. R. (1996). A history of Ukraine (p. 149). Toronto. [In English].

9. Yakovenko, N. (2010). A "portrait" and "self-portrait" of the borderlands: the cultural and geographic image of "Ukraine" in the sixteenth and early seventeenth centuries. In O. A. Andriewsky, Z. E. Kohut, S. Plokhy, and L. Wolff, Eds., Tentorium honorum: essays presented to Frank E. Sysyn on his sixtieth birthday (p. 499). Toronto. [In English].

10. Odnorozhenko, O. (2012). Ukrainska ruska elita doby serednovichchia i rannoho modernu: struktura ta vlada [Ukrainian Russian elite of Middle Ages and Early Modern Times: structure and government] (pp. 251-253). Kyiv. [In Ukrainian].

11. Head, R. H. (2008). Jenatsch's axe: social boundaries, identity, and myth in the era of the Thirty Years' War (pp. 34-35). Rochester, NY. [In English]; how the same principle applied to Ruthenia is discussed in Sysyn, F. E. (1982). Regionalism and Political Thought in Seventeenth-Century Ukraine: The Nobility's Grievances at the Diet of 1641. In Harvard Ukrainian Studies, Vol. 6, No. 2, pp. 171-172. [In English].

12. Yakovenko, N. (1993). Zdobutky i vtraty Liublinskoi unii [Achievements and losses of Lublin Union]. In Kyivska starovyna [Kyiv antiquity], 3, p. 82. [In Uktrainian]. This parallel between the Union of Lublin and cultural change in the Ukrainian lands reemerges in her later work: Yakovenko, N. (2002). Topos "ziednanykh narodiv" u panehirykakh kniaziam Ostrozkym i Zaslavskym (bilia vytokiv ukrainskoi identychnosti) [Topos of "connected nations" in the panegyrics to Ostrogski and Zasławski princes (origins of Ukrainian identity)]. In Paralelnyi svit: doslidzhennia z istorii uiavlen ta idei v Ukraini XVI-XVII st. [Parallel world: studies of the history of conceptions and ideas in Ukraine in the 16-17th centuries] (p. 243). Kyiv. [In Ukrainian]. 
13. Yakovenko, N. (1993). Zdobutky i vtraty Liublinskoi unii [Achievements and losses of Lublin Union]. In Kyivska starovyna [Kyiv antiquity], 3, pp. 83-84. [In Ukrainian].

14. Kaminskyi, A. S. (2011). Istoriia Rechi pospolytoi yak istoriia bahatokh narodiv, 1505-1795. Hromadiany, ikhnia derzhava, suspilstvo, kultura [History of Rzeczpospolita as the history of multiple nations. 1505-1795. Citizens, their state, society and culture] (p. 63). Kyiv. [In Ukrainian].

15. Sysyn, F. E. (1985). Between Poland and the Ukraine. The dilemma of Adam Kysil, 1600-1653 (p. 35). Cambridge, MA. [In English].

16. Yakovenko, N. (2002). Polsha i poliaky u shkilnykh pidruchnykakh istorii, abo vidlunnia dalekoho i blyzkoho mynuloho [Poland and Polish people in school history workbooks or the echo of far and near past]. In Paralelnyi svit: doslidzhennia $z$ istorii uiavlen ta idei v Ukraini XVI-XVII st. [Parallel world: studies of the history of conceptions and ideas in Ukraine in the 16-17th centuries] (p. 369). Kyiv. [In Ukrainian].

17. See Sharipova, L. (2015). Orthodox reform in the Polish-Lithuanian Commonwealth. In H. Louthan, G. Murdock, Eds., A Companion to the Reformation in Central Europe (pp. 223-253, Brill's companions to the Christian tradition, 61). Leiden, Boston. [In English].

18. Levitckii, O. (1882). Sotcinianstvo v Polshe i Iugo-Zapadnoi Rusi [Socinianism in Poland and South-West Rus]. In Kievskaia starina [Kyiv antiquity], 2, p. 29. [In Russian].

19. Yakovenko, N. (2002). Relihiini konversii: sproba pohliadu zseredyny [Religious conversions: an attempt to look from the inside]. In Paralelnyi svit: doslidzhennia $z$ istorii uiavlen ta idei $v$ Ukraini XVI-XVII st. [Parallel world: studies of the history of conceptions and ideas in Ukraine in the 16-17th centuries] (p. 33). Kyiv. [In Ukrainian].

20. Levitckii, O. (1882). Sotcinianstvo v Polshe i Iugo-Zapadnoi Rusi [Socinianism in Poland and South-West Rus]. In Kievskaia starina [Kyiv antiquity], 2, p. 56. [In Russian].

21. Crăciun, M. (1997). Protestantism and Orthodoxy in $16^{\text {th }}$-Century Moldavia. In K. Maag, Ed., The Reformation in Eastern and Central Europe (p. 133). Aldershot. [In English]; Dmitriev, M. (2007). Western Christianity and Eastern Orthodoxy. In Po-Chia Hsia, R., Ed., Reform and Expansion, 1500-1660 (pp. 333- 334, The Cambridge History of Christianity, 6). Cambridge. [In English].

22. Williams, G. (1978). Protestants in the Ukraine during the Period of the PolishLithuanian Commonwealth. In Harvard Ukrainian Studies, 2, p. 42. [In English].

23. By 1649 only twelve seats were held by secular Protestant and Orthodox senators: Yakovenko, N. (2002). Relihiini konversii: sproba pohliadu zseredyny [Religious conversions: an attempt to look from the inside]. In Paralelnyi svit: doslidzhennia $z$ istorii uiavlen ta idei v Ukraini XVI-XVII st. [Parallel world: studies of the history of conceptions and ideas in Ukraine in the 16-17th centuries] (p. 34). Kyiv. [In Ukrainian].

24. Pamiatniki polemicheskoi literatury v Zapadnoi Rusi [Polemic literature memorials in Western Europe] (Vol. 3, pp. 213-114, Russkaia istoricheskaia biblioteka [Russian historical library], 19). (1903). Saint Petersburg. [In Russian]. 
25. See Levitckii, O. (1883). Predislovie [Preface]. In Arkhiv Iugo-Zapadnoi Rossii [Archive of South-West Russia], Pt. 1, Vol. 4, pp. 48-49. Kyiv. [In Russian]; Dovbyshchenko, M. V. (2008). Volynska shliakhta u relihiinykh rukhakh kintsia XVI-pershoi polovyny XVII st. [Noble people of Volyn in religious movements of the late 16th - first half of the 17th centuries] (pp. 465-466). Kyiv. [In Ukrainian].

26. See Yakovenko, N. (2002). Relihiini konversii: sproba pohliadu zseredyny [Religious conversions: an attempt to look from the inside]. In Paralelnyi svit: doslidzhennia $z$ istorii uiavlen ta idei $v$ Ukraini XVI-XVII st. [Parallel world: studies of the history of conceptions and ideas in Ukraine in the 16-17th centuries] (pp. 38-39). Kyiv. [In Ukrainian].

27. See Jobert, A. (1974). De Luther à Mohila: la Pologne dans la crise de la Chrétienté, 1517-1648 (p. 322). Paris. [In French].

28. Gudziak, B. (1998). Crisis and reform: the Kyivan Metropolitanate, the Patriarchate of Constantinople, and the genesis of the Union of Brest. Cambridge, MA. [In English].

29. Princess Anna Koretska-Khodkevychivna ( $† 1626)$ converted to Calvinism before moving on to Antitrinitarianism and some form of "Judaising": Fond 312, Unit 60 (367), Folio 10 re. Institute of Manuscript, V. Vernadsky National Library of Ukraine, Kyiv, Ukraine. [In Ukrainian]; also Arkhiv Iugo-Zapadnoi Rossii [Archive of SouthWest Russia], Pt. 1, Vol. 7, p. 66. (1887). Kyiv. [In Russian]; Yakovenko, N. (2011). "Pogreb tilu moiemu vybyraiu s predky moiemy": mistsia pokhovan volynskykh kniaziv ["I choose my grave to be where my ancestors are buried": burial places of Volyn princes]. In Ukraina: kulturna spadshchyna, natsionalna svidomist, derzhavnist [Ukraine: cultural heritage, national conscience and sovereignty], pp. 784-808. Lviv. [In Ukrainian]; Yakovenko, N. (2012). Dzerkala identychnosti: doslidzhennia z istorii uiavlen ta idei v Ukraini XVI - pochatku XVIII stolittia [Mirrors of identity: studies of the history of conceptions and ideas in Ukraine in the 16th - early 18th centuries] (pp. 114-115.). Kyiv. [In Ukrainian].

\section{Sharipova}

Polonisation and all that, or religious identity and cultural change in Ruthenia: the Union of Lublin and the myths of «polonisation».

The article presents a review of an obsolete historiographic statement saying that an ultimate aftermath of the Union of Lublin signed in Poland in 1569, which caused the incorporation of Ukrainian lands of Grand Duchy of Lithuania to the Kingdom of Poland, was the forced polonisation of Orthodox people. As way of replacement for this oversimplified scheme, grounded on Ukrainian populist historiography of the 19th ct., complemented with the elements of Polish nationalistic and Russian imperial historiographic traditions, the author presents a new model, based on an assimilation formula. According to the formula, Orthodox szlachta people conversion to Protestantism and later to Catholicism initiated their loss of self-identification with Ukraine-Ruthenia cultural space. The process intensified as the Orthodox Church lost its legitimate status after the Church Union of Brest of 1596 and finished with an ultimate merger of this social group with the Polish Catholic elite in the early 17th century. 
Key words: historiography, Union of Lublin of 1569, Church Union of Brest of 1596, polonisation, religious conversion, self-identification.

\begin{abstract}
Л. В. Шарипова
Полонизация и все такое, или религиозная идентичность и культурные трансформации в Украине-Руси: Люблинская уния и миф о «полонизации».

Предложен пересмотр устаревшего тезиса в историографии о том, что кардинальным следствием Люблинской унии Речи Посполитой 1569 г., в результате которой украинские земли Великого княжества Литовского стали частью Королевства Польского, явилась насильственная полонизация православного населения. Взамен этой упрощенной схемы, уходящей своими корнями в украинскую популистскую историографию XIX ст. с элементами польской националистической и российской имперской историографических традиций, разработанная автором модель берет за основу ассимиляционную формулу. Согласно ей, именно религиозные конверсии второй половины XVI в., в ходе которых представители православной шляхты совершали переход сначала в протестантские конфессии, а позже в католицизм, стали первым шагом к утере ими самоидентификации с культурным контекстом Украины-Руси. Процесс ускорился с утратой православной церковью легитимного статуса после Брестской церковной унии 1596 г. и завершился окончательным слиянием данной социальной группы с польской католической элитой в начальные десятилетия XVII в.

Ключевые слова: историография, Люблинская уния 1569 г., Брестская церковная уния 1596 г., полонизация, религиозные конверсии, самоидентификация.
\end{abstract}

